Vol. 44, N. 4 : pp. 411 - 418, December, 2001

ISSN 1516-8913 Printed in Brazil

\title{
Occurrence of Larvae and Juveniles of Eucinostomus argenteus, Eucinostomus gula, Menticirrhus americanus, Menticirrhus littoralis, Umbrina coroides and Micropogonias furnieri at Pontal do Sul beach, Paraná
}

\author{
Rodrigo Santiago Godefroid*; César Santos; Marion Hofstaetter and Henry Louis Spach \\ Centro de Estudos do Mar-UFPR,. Av. Beira Mar, s/n. 83255-000. Pontal do Sul - PR, Brazil
}

\begin{abstract}
Despite its importance, most ichthyoplankton studies in the South-Southeastern coast of Brazil, have been accomplished on the continental shelf. Regarding the beach environment, recognized as a nursery, little is known about the ichthyoplankton. We analyzed 288 samples collected with a 18 by $2 \mathrm{~m}$ seine net, $1 \mathrm{~mm}$ mesh and a conical plankton net, with a mesh of $300 \mu \mathrm{m}$ and a $60 \mathrm{~cm}$ mouth. Eucinostomus argenteus comprised $78 \%$ of the larvae and juveniles caught in the samples. The occurrence of gerreids was strongly concentrated in the summer, while the Menticirrhus littoralis, Menticirrhus americanus and Umbrina coroides were present during all seasons. M.littoralis was most abundant during spring, while M. americanus and U. coroides dominated during winter. For all species, the largest captures occurred during low tide. Environmental preferences are indicated in the principal component analysis, with the larvae and juveniles of E. argenteus and E. gula positively correlated with smaller waves and smaller morphodynamism, whereas M. americanus, U. coroides and M. furnieri seem to prefer periods with lower temperatures and larger morphodynamism.
\end{abstract}

Key words: Fish larvae, Surf Zone, Brazil

\section{INTRODUCTION}

Faunistic surveys have revealed that the estuary is not the only and most important coastal ecosystem used as a nursery. Studies about beach ichthyofauna show the presence of several fish species, mainly in the juvenile stage, which indicate the importance of the beach environment as a nursery (Robertson and Lenanton, 1984; Lasiak, 1984 a,b).

In spite of the importance of beaches for the recruitment of fish, few studies deal with communities of fish in Brazilian beaches (Cunha,
1988; Paiva-Filho and Toscano., 1987; MonteiroNeto, 1990; Graça Lopes et al., 1993), especially about the occurrence of fish larvae in this habitat (Matsuura and Nakatani, 1979). As a result, the present study has the objective of analyzing the occurrence of larvae and juveniles of two species of Gerreidae: Eucinostomus argenteus and Eucinostomus gula; and four species of Sciaenidae: Menticirrhus americanus, Menticirrhus littoralis, Umbrina coroides and Micropogonias furnieri in the surf zone, the latter being important commercially.

" Author for correspondence 


\section{MATERIAL AND METHODS}

The study area is located in Pontal do Sul Beach, in the south corner of Paranaguá Bay (25 16' 34" $\mathrm{S}, 48^{\circ} 17^{\prime}$ 42" W), southern Brazil. The beach, protected from the direct action of the waves by Mel and Galheta Islands, is of the reflective type with an inclination of $1.76^{\circ}$ in the intertidal region and $2.74^{\circ}$ in the subtidal region (Tavares, 1996).

Juveniles were obtained in the surf zone using an 18 by $2 \mathrm{~m}$ seine net, with a $1 \mathrm{~mm}$ mesh. Larvae were collected with a conical plankton net, with a mesh of $300 \mu \mathrm{m}$ and a $60 \mathrm{~cm}$ mouth. Samples were taken biweehly from May 1993 to April 1994, at high tide and low tide of the syzygial and quarter tides. Hauling was parallel

to the coast, in the direction of the current, at a depth below $1.70 \mathrm{~m}$, along a previously defined $100 \mathrm{~m}$ strip of beach, for each net type. Simultaneously to the collection, salinity (with a portable refractometer), water temperature (mercury thermometer), wave height and period, were obtained. The climatic

data, such as air temperature,wind direction and intensity were obtained at the meteorological station of the Centro de Estudos do Mar; and rainfall was obtained at a metereological station located in Guaraguaçu River, not very far from the studied area.. The morphodynamic state of the beach was evaluated using the ômega parameter calculation (Dean 1973) and surf-scaling (Guza and Imman 1975).

Plankton samples were conditioned in polyethylene flasks and preserved with $4 \%$ buffered formalin solution, while the seine net samples were conditioned in plastic sacks. At the laboratory, fish from the seine net were frozen and later identified to species level. Fish larvae were selected from the total volume of the plankton sample under a stereoscopic microscope, identified, and later measured and classified according to their development stage (Ahlstrom and Ball 1954).

In an attempt to identify environmental preferences, a Principal Component Analysis was applied (Legendre and Legendre 1983). In this study, the seasons were defined in the following way: September to November $=$ spring; December to February $=$ summer; March to May $=$ autumn and June to August $=$ winter.

\section{RESULTS AND DISCUSSION}

Mean monthly water temperature presented the typical seasonal pattern of the studied area, with smaller means from June to September and a progressive increase between spring and summer, followed by a decrease in autumn. Salinity did not present a seasonal trend, there being considerable differences between months in the same season, particularly during winter and spring. Larger mean rainfall occurred during summer and autumn, than winter and spring, with the exception of September. Rainfall varied from a minimum of 0 $\mathrm{mm}$ in November to a maximum of $352.4 \mathrm{~mm}$ in February; with a clear correlation between an increase in the rainfall and a decrease in the salinity. Considering the monthly occurrences, the North and Northwest winds prevailed from the end of autumn to the end of winter, and during spring a larger frequency of southwest, south and southeast winds was observed. The monthly average wave height was larger during winter and spring, than during summer and autumn. In the morphodynamical state of the beach environment, the values of the omega parameter varied between 0.02 and 0.05 , characterizing the beach as reflective in all the studied period (Tab. 1). 
Table 1- Environmental parameters (means) and morphodynamic indexes (means) registered for Pontal do Sul beach from May 1993 to April 1994. $(\mathrm{S}=$ salinity, $\mathrm{T}$ water $=$ water temperature, $\mathrm{T}$ air = air temperature, Wind dir = wind direction, Wind $\mathrm{Vel}=$ wind speed, $\mathrm{P}=$ wave period, $\mathrm{Hb}=$ wave height, $\Omega=$ ômega, $\varepsilon=$ surf - scaling parameter).

\begin{tabular}{|c|c|c|c|c|c|c|c|c|c|c|}
\hline \multirow[t]{2}{*}{ Months } & \multirow[b]{2}{*}{$\mathrm{S}$} & \multirow[b]{2}{*}{$\begin{array}{c}\text { T water } \\
\left({ }^{0} \mathrm{C}\right)\end{array}$} & \multirow[b]{2}{*}{$\begin{array}{l}\mathrm{T} \text { air } \\
\left({ }^{0} \mathrm{C}\right)\end{array}$} & \multicolumn{2}{|c|}{ Parameters } & \multirow[b]{2}{*}{ Wind vel $(\mathrm{m} / \mathrm{s})$} & \multirow[b]{2}{*}{$\mathrm{P}(\mathrm{s})$} & \multirow[b]{2}{*}{$\mathrm{Hb}(\mathrm{cm})$} & \multicolumn{2}{|c|}{ Morphodynamism } \\
\hline & & & & $\begin{array}{c}\text { Rainfall } \\
\text { (mm) }\end{array}$ & $\begin{array}{c}\text { Wind } \\
\text { dir }\end{array}$ & & & & $\Omega$ & $\varepsilon$ \\
\hline Mav & 30.7 & 22,2 & 21.52 & 103.8 & NW & 1,87 & 9 & 30 & 0,02 & 4,14 \\
\hline June & 29,9 & 16,45 & 18,75 & 64,8 & NW & 1,85 & 11,5 & 42,5 & 0,03 & 3,59 \\
\hline July & 34,8 & 20,2 & 17,87 & 65,1 & $\mathrm{~N}$ & 2,29 & 8,2 & 40 & 0,04 & 6,64 \\
\hline August & 32,1 & 18,4 & 17,03 & 10,4 & $\mathrm{~N}$ & 1,92 & 6,6 & 32 & 0,04 & 8,20 \\
\hline September & 31,2 & 18,9 & 18,3 & 320,3 & SW & 2,85 & 8,25 & 50 & 0,05 & 8,20 \\
\hline October & 28,6 & 22,2 & 21,62 & 49,5 & $\mathrm{~S}$ & 2,72 & 8,6 & 42 & 0,04 & 6,34 \\
\hline November & 33,7 & 23,9 & 24,81 & 0 & SE & 3,49 & 8,6 & 40 & 0,03 & 6,04 \\
\hline December & 31,4 & 26,4 & 25,55 & 161,5 & $\mathrm{E}$ & 4,05 & 8,6 & 30 & 0,03 & 4,53 \\
\hline January & 31,4 & 25,2 & 24,98 & 249,1 & SE & 3,46 & 12 & 25 & 0,02 & 1,94 \\
\hline February & 27,1 & 27 & 26,91 & 352,4 & $\mathrm{~N}$ & 2,27 & 9,6 & 28,8 & 0,02 & 3,49 \\
\hline Marçh & 27,7 & 26,4 & 25,38 & 302,3 & SE & 2,9 & 11,2 & 30 & 0,02 & 2,67 \\
\hline April & 30,1 & 24,35 & 23,03 & 300,6 & SW & 2,38 & 9,2 & 30 & 0,02 & 3,96 \\
\hline
\end{tabular}

A total of 5288 fish were captured, with $E$. argenteus dominating numerically the samples $(78$ $\%)$ and the other species presenting proportions of less than $8 \%$ of the total capture (Tab. 2). This dominance of larvae and juveniles of gerreids in beach hauls was observed previously in Anchieta
Island, on the northern coast of the State of São Paulo (Matsuura and Nakatani, 1979). In the surf zone E. argenteus is the most common one (Saul and Cunningham, 1995), while E. gula seems to prefer the inner areas of estuaries (RamirezVillaroel, 1994).

Table 2 - General capture data for larvae and juveniles of six fish species at Pontal do Sul Beach, between May 1993 and April 1994.

\begin{tabular}{|c|c|c|c|c|c|c|}
\hline TAXON & $\begin{array}{l}\text { Post-flexion } \\
\text { (n) }\end{array}$ & $\begin{array}{l}\text { Juvenile } \\
\text { (n) }\end{array}$ & $\begin{array}{l}\text { Proportion } \\
\text { captured \% }\end{array}$ & $\begin{array}{c}\text { Period of } \\
\text { occurrence }\end{array}$ & $\begin{array}{l}\text { Temperature } \\
\text { range }^{\circ} \mathrm{C}\end{array}$ & $\begin{array}{l}\text { Salinity } \\
\text { range }\end{array}$ \\
\hline Eucinostomus argenteus (Baird and Gerard, 1854) & 4106 & 87 & 77,6 & Dec - Jun & $16-29$ & $19-34$ \\
\hline Eucinostomus gula (Cuvier, 1830) & 252 & 5 & 4,9 & $\mathrm{Dec}-\mathrm{Feb}$ & $22-27,5$ & $25-32$ \\
\hline Menticirrhus americanus (Linnaeus, 1758) & 238 & 61 & 5,6 & Whole year & $15-28$ & $23-35$ \\
\hline Menticirrhus littoralis (Holbrook, 1860) & 9 & 48 & 1,1 & Whole year & $15-28$ & $25-35$ \\
\hline Micropogonias furnieri (Desmarest, 1823) & 377 & 7 & 7,3 & $\begin{array}{l}\text { Jan, - Feb, } \\
\text { May - Out. }\end{array}$ & $15-28$ & $23-35$ \\
\hline Umbrina coroides (Cuvier, 1830) & 5 & 183 & 3,6 & $\begin{array}{l}\text { Jan - Feb, Apr, } \\
\text { Jun - Aug, Oct }\end{array}$ & $15-26$ & $28-35$ \\
\hline
\end{tabular}

For all the species, the largest captures occurred at low tide, with larger captures during nocturnal low tide. The exception for this pattern were $M$. americanus and $U$. coroides (Fig. 1). A greater number of post-flexion stage occurred in $E$. argenteus, E. gula, M. americanus and M. furnieri, with the prevalence of juveniles in $M$. littoralis and $U$. canosai (Figs. 2 to 7 ). 


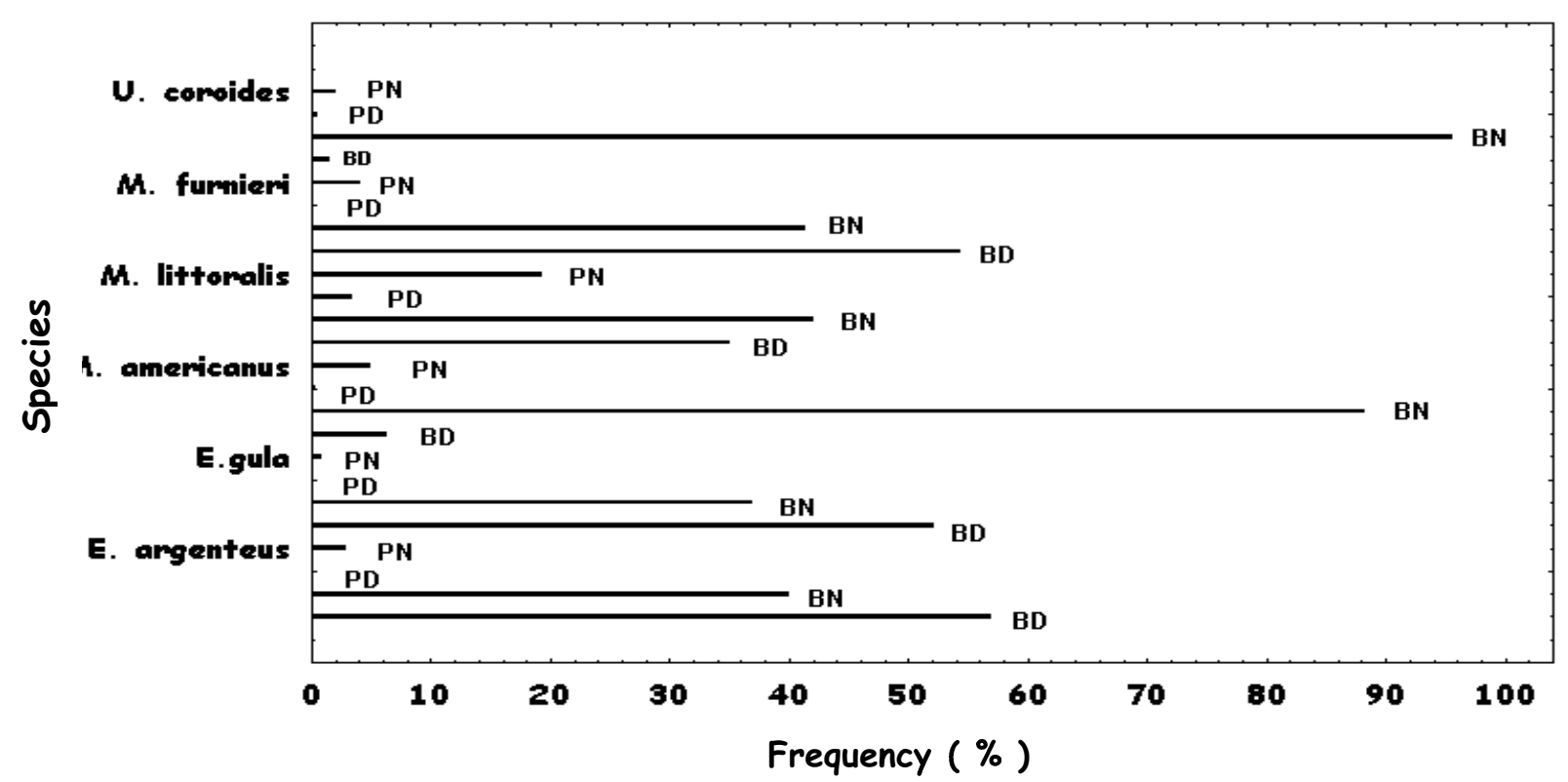

Figure 1 - Capture frequency of the species during the diurnal low tide (BD), nocturnal low tide (BN), diurnal high tide (PD), nocturnal high tide (PN) at Pontal do Sul beach, Paraná.

Specimens of E. argenteus were captured from summer to the end of autumn, with the largest occurrences of larvae in December and January (Fig. 2). The pattern of occurrence of larvae of $E$. gula was similar to that of E. argenteus, although there was a reduced abundance of juveniles in the area for the former (Fig. 3). In the surf zone,
Matsuura and Nakatani (1979) found larvae of Eucinostomus sp. throughout the year, with peaks in the summer as well. The data from this study, like that of Matsuura and Nakatani (1979), seem to indicate a more intense spawning in the warmest period of the year.
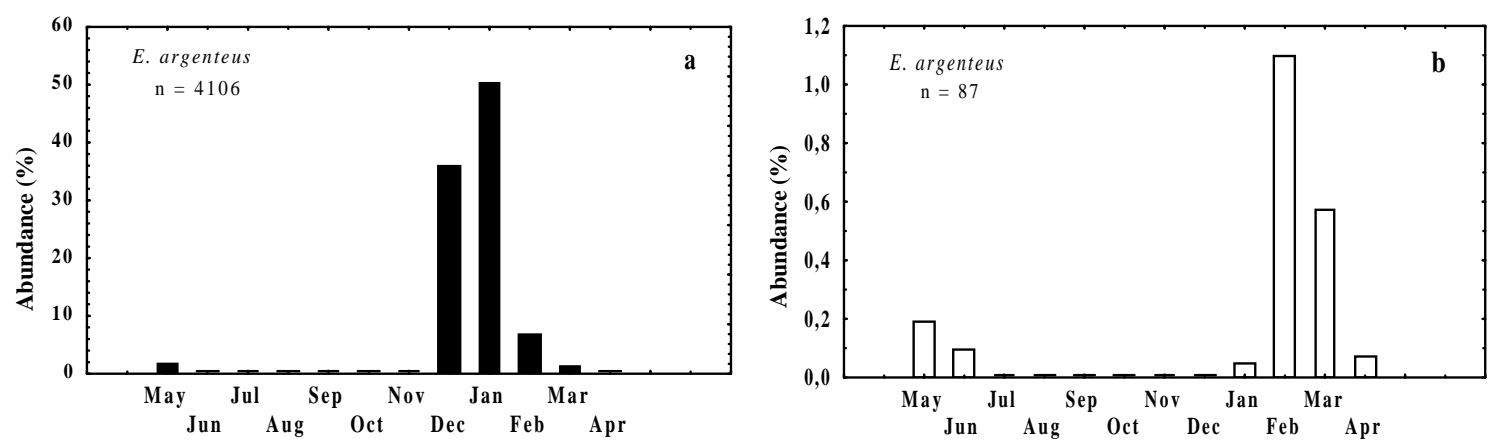

Figure 2 - Monthly relative abundance (\%) of larvae (a) and juveniles (b) of Eucinostomus argenteus at Pontal do Sul beach, Paraná

The species $M$. americanus presented annual occurrence with a larger presence of post-flexion larvae in winter (Fig. 4). On the east coast of United States, the species breeds on the continental shelf (Hildebrand and Cable, 1930) during spring and summer (Powles and Stender,
1978), and the larvae are transported to the coast (Cowan and Shaw, 1988). 

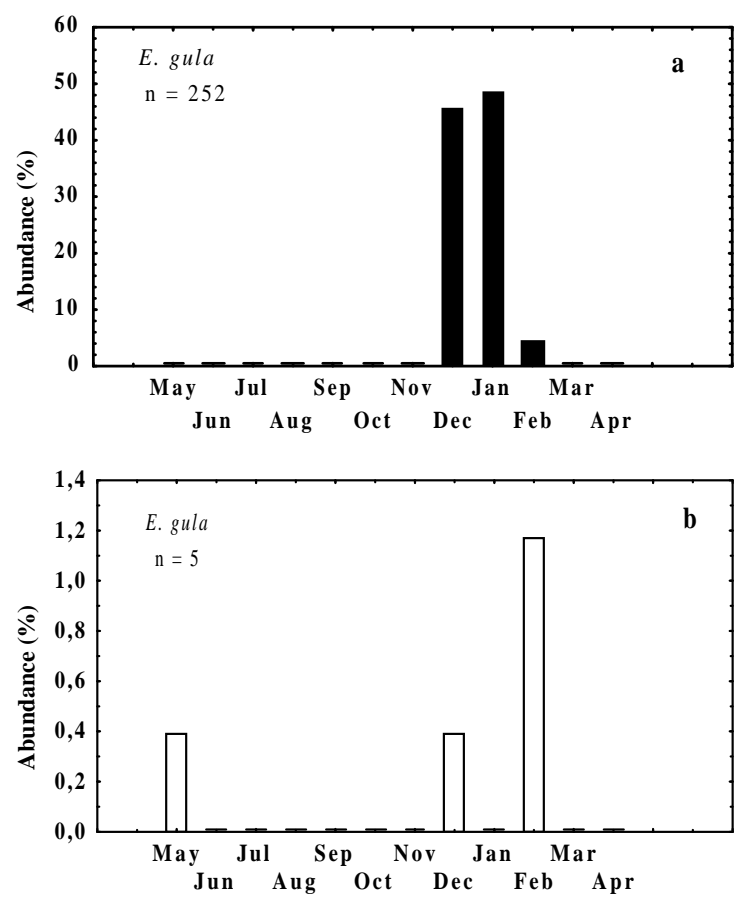

Figure 3 - Monthly relative abundance (\%) of larvae (a) and juveniles (b) of Eucinostomus gula at Pontal do Sul beach, Paraná.
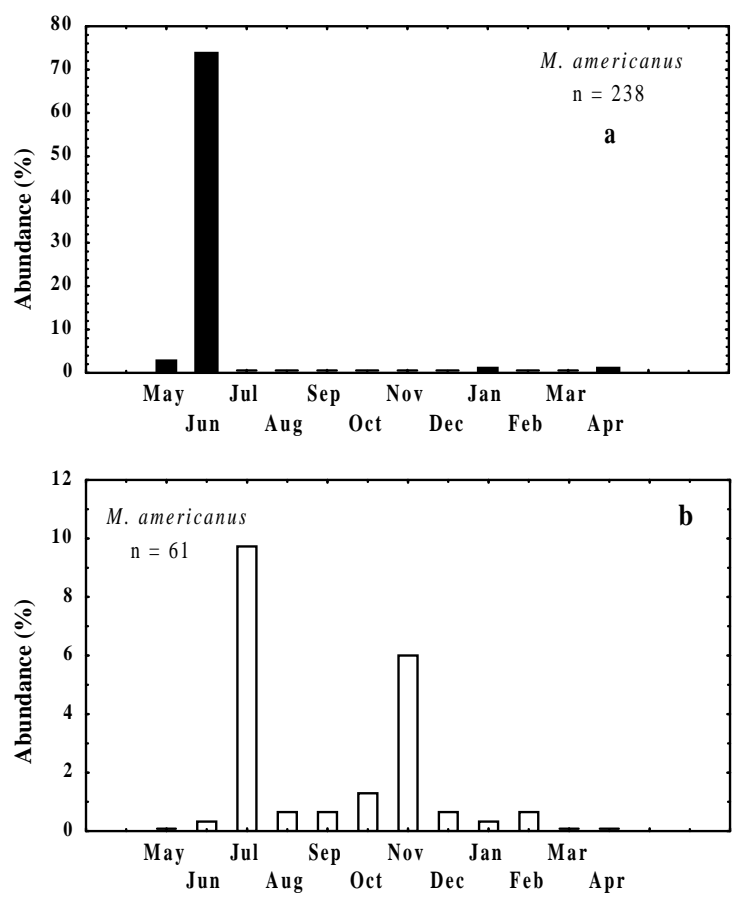

Figure 4 - Monthly relative abundance (\%) of larvae (a) and juveniles (b) of Menticirrhus americanus at Pontal do Sul beach, Paraná.

Sinque (1980) studied the sciaenid larvae in the estuary of Cananéia, on the southern coast of the
State of São Paulo, Brazil and found larvae of $M$. americanus in the post-flexion stage from June to December, concluding that the spawning period of this species should occur between winter and spring. The results of the present study do not allow us to conclude about the spawning period of the species in the region, however, a winter spawning seems unlikely. Although M. littoralis is present on the beach during the whole year, it occurred in much smaller quantities than $M$. americanus, especially in the larval stage (Fig. 5). This smaller presence in the area suggestes the preference of the species for exposed beaches (McMichael and Ross, 1987) and that the juveniles rarely enter into the estuarine area (Hildebrand and Cable, 1930).
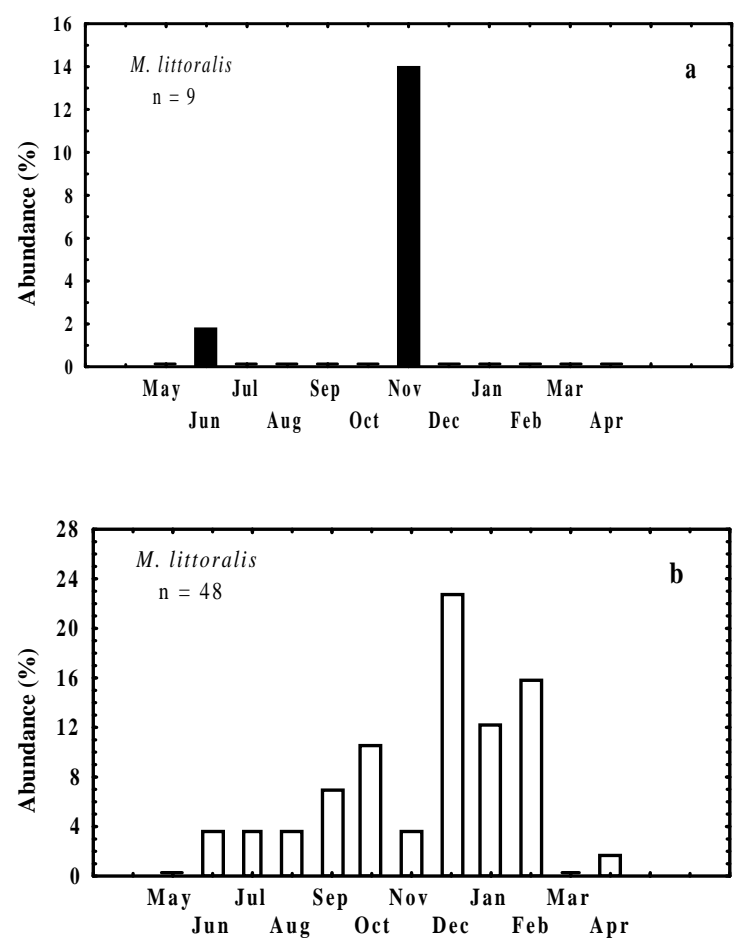

Figure 5 - Monthly relative abundance (\%) of larvae (a) and juveniles (b) of Menticirrhus littoralis at Pontal do Sul beach, Paraná.

Most of the specimens of M. furnieri captured are larvae in the post-flexion stage, more frequent during winter and spring (Fig. 6). As in this study, Flores-Coto and Perez-Argudin (1991), observed that this species reaches the entrance of the estuaries in an advanced development stage, which would enable the active migration of the larvae to the most internal areas. The presence of juvenile specimens of $M$. furnieri throughout the year was observed previously in the estuaries of Cananéia 
(Sinque, 1981) and Patos Lagoon (Weiss, 1981; Muelbert and Weiss, 1991). The periods with larger abundance of larvae of $M$. furnieri at Pontal do Sul beach, coincide with those observed for the species in the Cananéia estuary (Sinque, 1980). In a more southerly estuary than the studied area, highest mean density of larvae of M. furnieri was observed during the summer ( Weiss, 1981; Muelbert and Weiss, 1991).
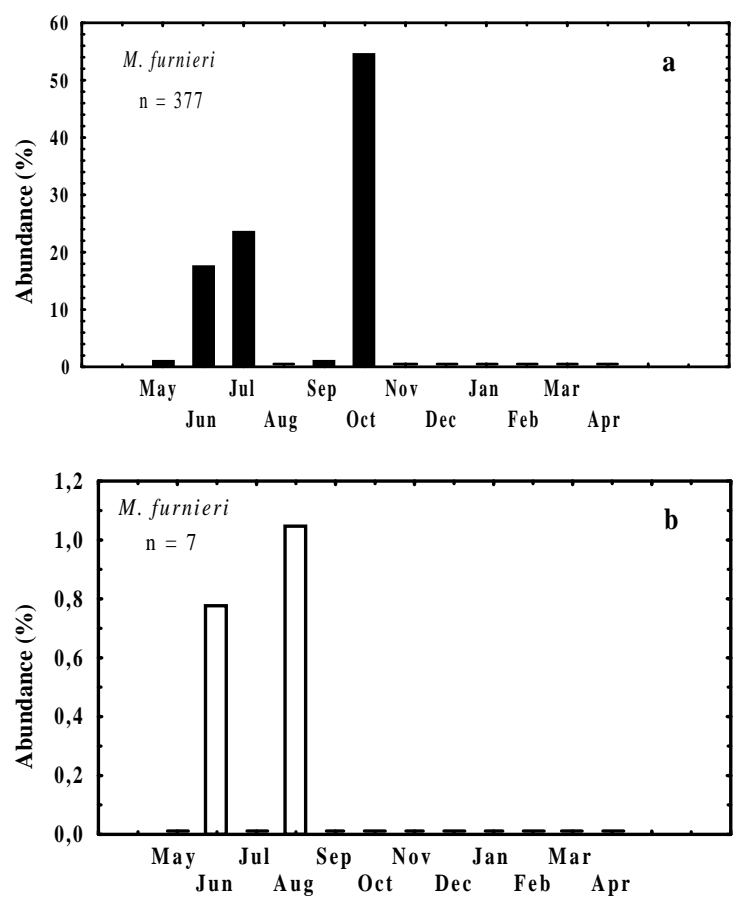

Figure 6 - Monthly relative abundance (\%) of larvae (a) and juveniles (b) of Micropogonias furnieri at Pontal do Sul beach, Paraná.

Juveniles of $U$. coroides were present in the area throughout the year, with larger frequencies in winter and spring (Fig. 7). Only five larvae of this species were captured in the surf zone of Pontal do Sul beach. The occurrence of juveniles of $U$. coroides in a beach environment throughout the year and in larger quantities during winter has been observed previously (Matsuura and Nakatani, 1979).
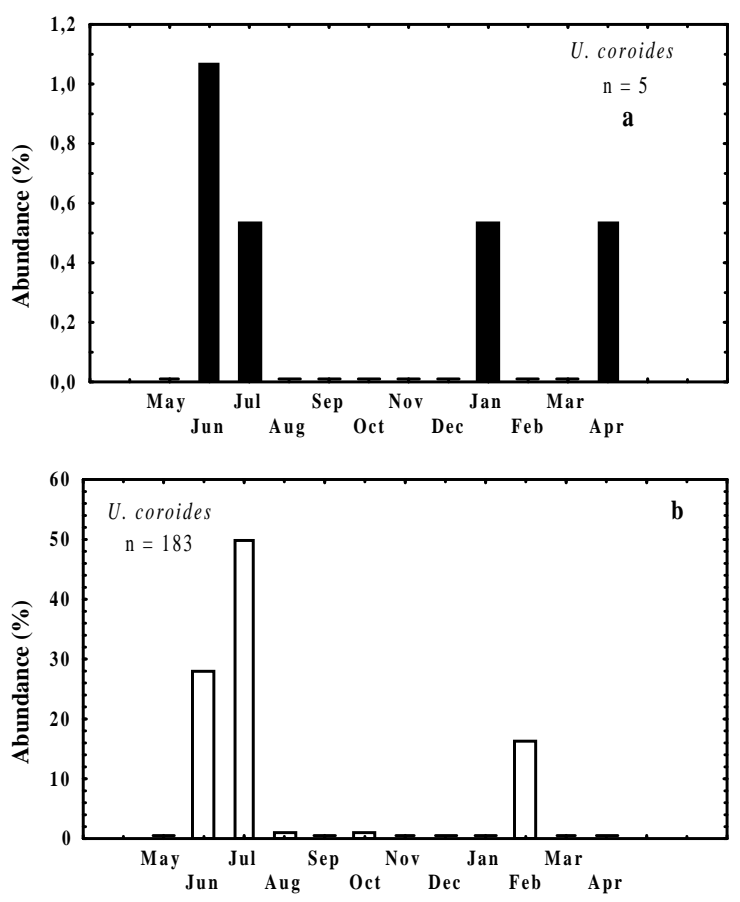

Figure 7 - Monthly relative abundance (\%) of larvae (a) and juveniles (b) of Umbrina coroides at Pontal do Sul beach, Paraná.

In the Principal Component Analysis, component I, responsible for $25.08 \%$ of the variation in the data, is related to the wave height and period and with the morphodynamic state of the beach, opposing winter samples, with larger waves and a larger morphodynamism, to summer ones, with smaller waves and a smaller morphodynamism. Larvae and juveniles of E. argenteus and E. gula are positively correlated with the summer condition, and on the contrary, there is a low occurrence of these species in the winter. Component II, responsible for $16.49 \%$ of the variation in the data, is related to the wind, precipitation and water temperature, opposing summer samples with a smaller intensity of winds, a larger precipitation and a higher water temperature, to winter ones, with opposite conditions. Larvae and juveniles of $M$. americanus, $U$. coroides and $M$. furnieri are positively correlated with the winter condition, on the contrary there was a low occurrence of these species in the warmer periods of the year. The species $M$. littoralis is little influenced by environmental conditions and appeared in small amounts during all the seasons of the year (Fig. 8). 


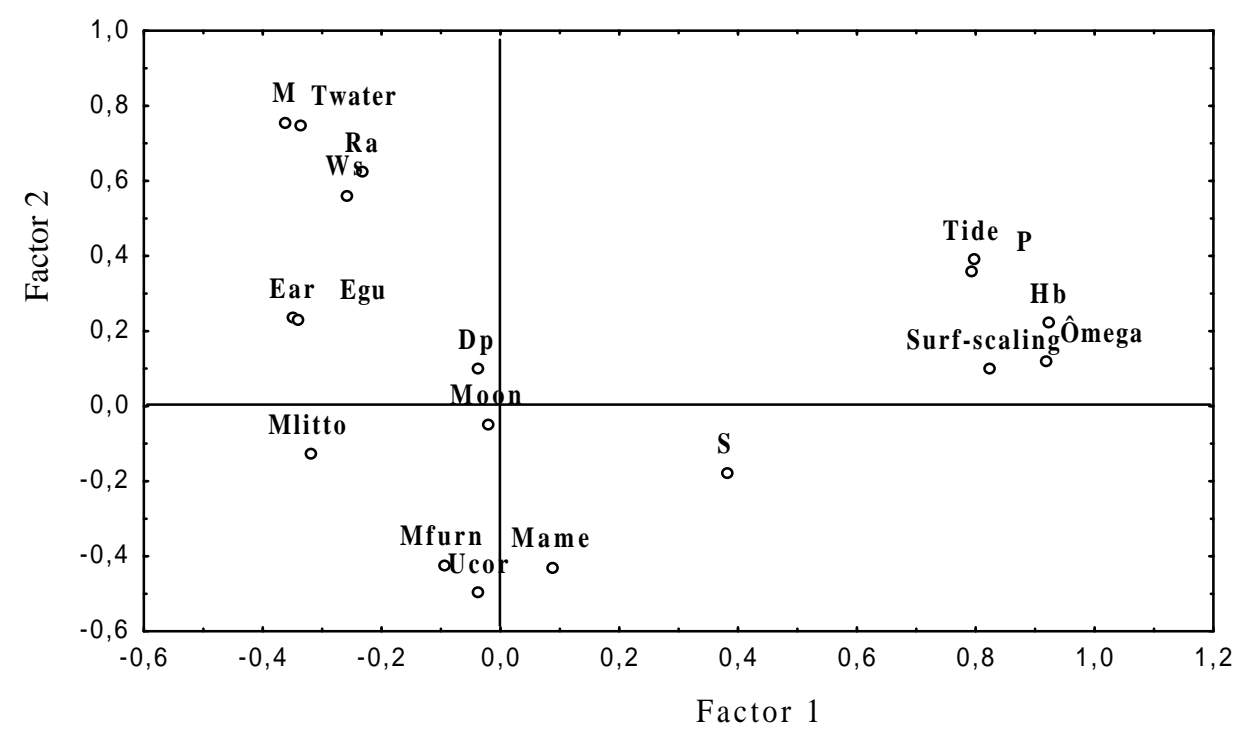

Figure 8 - Principal Component Analysis with simultaneous projection of the variables (species / physical chemical), with an interpretation of the components I and II. ( $\mathrm{S}=$ salinity, $\mathrm{T}$ water $=$ water temperature, $\mathrm{Ra}=$ Rainfall, $\mathrm{Ws}=$ wind speed, $\mathrm{P}=$ wave period, $\mathrm{Hb}=$ wave height, $\mathrm{Dp}=$ Day period, $\mathrm{M}=\mathrm{Month}$ Ear $=$ E. argenteus, $\mathrm{Egu}=E$. gula, Mame $=$ M. americanus, Mlitto = M. littoralis, Mfurn $=M$. furnieri, Ucor $=U$. coroides $)$.

\section{RESUMO}

Apesar da importância, a maioria dos estudos de ictioplâncton na costa sul-sudeste do Brasil, foram realizados sobre a plataforma continental. No que se refere ao ambiente praial, reconhecido como área de criação, pouco se sabe sobre o ictioplâncton. Foram analisadas 288 amostras coletadas com uma rede tipo picaré com $18 \times 2 \mathrm{~m}$ e malha de $1 \mathrm{~mm}$, e rede de plancton cônica, com malha de $300 \mu \mathrm{m}$ e boca de $60 \mathrm{~cm}$. A espécie $E$. argenteus totalizou $78 \%$ das larvas e juvenis capturados. A ocorrência dos gerreideos foi fortemente concentrada no verão, enquanto que Menticirrhus littoralis, Menticirrhus americanus e Umbrina coroides estiveram presentes em todas as estações do ano. $M$. littoralis foi mais abundante na primavera, enquanto que $M$. americanus e $U$. coroides dominaram no inverno. Em todas as espécies as maiores capturas ocorreram na baixa-mar. Preferências ambientais foram indicadas na análise de componentes principais, com as larvas e juvenis de $E$. argenteus e E. gula positivamente correlacionados com menores ondas e menor morfodinamismo, enquanto que $M$. americanus, $U$. coroides e $M$. furnieri parecem preferir períodos com menores temperaturas e maior morfodinamismo.

\section{AKNOWLEDGEMENTS}

We would like to thank the Centro de Estudos do Mar, Universidade Federal do Paraná, for financial support.

\section{REFERENCES}

Ahlstron, E. H. Z and Ball, L. (1954), In: Ontogeny and systematics of fishes. Based on an International Symposium Dedicated to the Memory of Elbert Halvor Ahlstrom. Spec. Pub. Am. Soc. of Ichth. and Herpt., (1) 1983.

Cunha, L. P. R. (1988), Aspectos comparativos da ictiofauna de zonas de arrebentação de praias do litoral do Paraná e do Rio Grande do Sul. Res. XV Cong. Bras. Zoo., Curitiba, 346p.

Cowan, J. H. Jr. and Shaw, R. F. (1988), The distribution, abundance, and transport of larval sciaenids collected during winter and early spring from the continental shelf waters off West Louisiana. Fish. Bull., 86(1), 129-142.

Dean, R. F. (1973), Heuristic models of sand transport in the surf zone. Proc. Ist. Austr. Conf. Cstl. Engin., 208-214. 
Flores-Coto, C. and Perez-Argudin, M. (1991), Efecto de la marea en el paso de larvas de Sciaenidos (Pisces) wn boca del Carmen, Laguna Campeche. Na. Inst. Cienc. Mar-Limnol. Univ. Nac. Auton. Mex., 18(1), 25-35.

Graça Lopes, R.; Severino Rodrigues, E.; Puzzi, A.; Pita, J. B; Coelho, J. A. P. and Freitas, M. L. (1993), Levantamento ictiofaunístico em um ponto fixo na Baía de Santos, Estado de São Paulo, Brasil. B. Inst. Pesca, 20, 7-20.

Guza, R. I. and Inman, D. L. (1975), Edge waves and beach and cusps. J. Geol. Res., 80(21), 2997-3013.

Hildebrand, S. F. and Cable, L. E. (1930), Development and life history of fourteen teleostean fishes at Beaufort, NC. U.S. Bureau of Fisheries Bulletin, 46, 383-488.

Lasiak, T. A $\left(1984^{\mathrm{a}}\right)$, Structural aspects of the surf zone fish assemblage at King's Beach, Algoa Bay, South Africa: Short - term fluctuations. Est. Coast. Shelf Sci., 18, 347-360.

Lasiak, T. A. (1984b), Structural aspects of the surf zone fish assemblage at King's Beach, Algoa Bay, South Africa: Long - term fluctuations. Est. Coast. Shelf Sci.,18(4), 459-483.

Legendre, L. and Legendre, P. (1983), Numerical ecology. Developments in environmental modelling, Elsevier Scientific Publishing Company, Amsterdam.

Matsuura, Y. and Nakatani, K. (1979), Ocorrência de larvas e jovens de peixes na Ilha Anchieta (SP), com algumas anotações sobre a morfologia da castanha, Umbrina coroides Cuvier, 1830. Bolm. Inst. Oceanogr. da USP, 28(1), 165-183.

McMichael, R. H. Jr and Ross, S. T. (1987), The relative abundance and feeding habits of juvenile kingfish (Sciaenidae: Menticirrhus) in a Gulf of Mexico surf zone. Northeast Gulf Sci, 9(2), 109-123.

Monteiro-Neto, C. (1990), Comparative community structure of surf zone fishes in the Chesapeake Bight and Southern Brazil. PhD Thesis, Faculty of the School of Marine Science, The college of William and Mary, Virginia, United States.
Muelbert, J. H. and Weiss, G. (1991), Abundance and distribution of fish larvae in the channel area of the Patos Lagoon Estuary. NOAA Tech. Rep., 95, 43-54.

Paiva Filho, A. M. and Toscano, A. P. (1987), Estudo comparativo e variação sazonal da ictiofauna na zona entre-marés do Mar Casado - Guarujá e Mar Pequeno - São Vicente, SP. Bolm. Inst. Oceanogr., São Paulo, 35(2), 153-165.

Powles, H. and Stender, B. W. (1978), Taxonomic data on the early life history stages of Sciaenidae of the south Atlantic bight of the United States. South Carolina Marine Resources Center Tech. Rep., 31, 1-64.

Ramirez-Villaroel, P. (1994), Estructura de las comunidades de peces de la Laguna de Raya, Isla Margarita, Venezuela. Cienc. Mar.., 20(1), 1-16.

Robertson, A. I. and Lenanton, R. C. J. (1984), Fish community structure and food chain dynamics in the surf zone of sandy beaches: The role of detached macrophyte detritus. J. Exp. Mar. Biol. Ecol., 84, 265-283.

Saul, A. C. and Cunningham, P. T. M. (1995), Comunidade Ictiofaunística da Ilha do Bom Abrigo, Cananéia, São Paulo, Brasil. 2- Lanço. Arq. Biol. Tecnol., 38(4), 1053-1069.

Sinque, C. (1980), Larvas de Sciaenidae (Teleostei) identificadas na região estuarina-lagunar de Cananéia. Bol. Zool. Univ. São Paulo, 5, 39-77.

Tavares, Y. (1996), Ecologia populacional de Mellita quinquesperforata Laske, 1778 (Echinodermata Echinoidea - Clyperasteroia) em diferentes praias do litoral do Paraná, Brasil. Master Thesis, Federal University of Paraná.

Weiss, G. (1981), Ictioplancton del Estuario de Lagoa dos Patos, Brasil. PhD Thesis, La Plata National University. 